\title{
EVALUATION OF A NOVEL PAN BREAD FORMULATED BY WHEAT/MILLET FLOUR DIFFERENT BLENDS
}

\author{
E.S. El-Poraie(1), A.E. El-Beltagy(2) and T. A. El-Adawy (2) \\ (1) Holding Company for Food Industries, Cairo, Egypt. \\ (2) Food Science and Technology Department, Faculty of Agriculture, Menoufia University, \\ Shibin El-Kom, Egypt.
}

Received: Nov. 11, 2018

Accepted: Dec. 9, 2018

ABSTRACT: The effect of substituting wheat flour (WF) with different levels $(10,20,30$ and $40 \%$ ) of millet flour (MF) on rheological properties and pan bread quality were investigated. Substituting WF with MFsignificantly $(p \leq 0.05)$ increased protein, fat contents and dough stretching while reduced carbohydrate, wet gluten, dry gluten, all solvent retention capacity parameters, lightness $\left(L^{*}\right)$, total color difference $\left(\Delta E^{*}\right)$ value, dough stability and water absorption. No significant $(P>0.05)$ difference was found in physical parameters and overall acceptability of pan bread between control and wheat formulated with up to $10 \%$ MF. Generally, the increase in the millet levels caused the increase in the lightness $\left(L^{*}\right)$ of crust and crumb color. The crumb $L^{*}$ became lighter $(p \leq 0.05)$ with incorporating a higher levels of WF. Also, pan bread formulated with $40 \% \mathrm{MF}$ had the highest $(p \leq 0.05)$ value of $b^{*}, c^{*}$ and total color difference. No significant difference $(p>0.05)$ was detected in hardness, springiness, cohesiveness and resilience between control and pan formulated with MF up to $30 \%$ (and up to $40 \%$ for adhesiveness, gumminess and chewiness). In addition, increasing the storage (at $\left.25^{\circ} \mathrm{C} \pm 2\right)$ time increased significantly $(p<0.05)$ hardness, gumminess and chewiness.

Key words: Millet flour, SRC, Rheological properties; pan bread; Texture profile; physical properties.

\section{INTRODUCTION}

In Egypt, wheat is the most important grain crop. Egypt is the world's biggest wheat importer and the General Authority for Supply Commodities of the Ministry of Supply and Internal Trade of Egypt alone is the world's biggest wheat purchaser. It is thus understandable that wheat is a product of paramount importance to Egypt and wheat policy is a priority for the government. The importance of wheat policy is reinforced by Egypt's specific social realities: with over a quarter of the Egyptian population living under the poverty line, assuring the food security of all citizens is a key challenge for the government (FAO 2017).

In recent years, many researches have studied substitutes wheat flour with other grain such as barley (Izydorczyk and Dexte 2008), buckwheat (Kaur et al., 2015), rice flour (Chung et al., 2014), pearl millet flours (Balasubramanian and Viswanathan 2010; Rai et al., 2014; and Altındag et al., 2015), oat flour (Duta and Culetu, 2015), amaranth (Barca et al., 2010) and corn flour (Altındag et al., 2015). However, local crops like millet flour could be a substitution to wheat flour to fill this gap. Pearl millet show nutritional and texture features, which make them suitable for replacing, at least in part, traditional cereal-based products.

Pearl millet (Pennisetum glaucum Synonyms: Pennisetum americanum, Pennisetum typhoides) a small-seeded crop known as Bajra (Gull et al., 2012) is the sixth most important cereal grain worldwide (Saleh et al., 2013 and Amadou et al., 2013). It can grow under adverse ecological conditions and can tolerate poor soil and a certain degree of drought 
better than any cereal crop (Shimelis 2009; Jideani and Jideani 2011; Saleh et al., 2013 and Devi et al., 2014). It can also survive in semi-arid and arid lands and is well adapted to drought and sandy acid soil of low fertility (Osman Magdi 2011; FAOSTAT 2011; Yadav and Rai 2013 and Amadou et al., 2013). Most of which are adapted to hot, dry climates (Supriya et al., 2016).

Several studies indicated the possibilities of incorporating pearl millet and other flours in wheat flour at various levels for producing bread, biscuit, breakfast cereals and other snacks (Krishnan and Prabhasankar 2010; Krishnan et al., 2011; Singh et al., 2012 and Angioloni and Collar 2012a), cake (Desai et al., 2010), pasta (Kaur et al., 2012 and Balasubramanian et al., 2014a,b)

Providing the millet similar to rice and wheat would improve its acceptability (Saha et al., 2011). With the increase in substitution percentage of millet flours, the firmness value significantly was decreased ( $p \leq 0.05)$ by Gull, et al., (2015).

Ballolli et al. (2014) reported that the physical characteristics of the bread decreased with increased substitution levels of millet flour, it might be due to the decrease in the proportion of the gluten content. Mamata et al. (2015) who reported that no change $(p>0.05)$ was detected in loaf weight between wheat flour and substitution with $10 \%$ millet flour incorporated bread. Meanwhile, increase substitution of higher levels showed a more irregular structure with most gluten layers without a continuous distribution and surrounded by large starch granules (Monika et al., 2015) and also the crumb firmness was the highest for the bread (Regine et al., 2013).

The aim of the present research was to evaluate the effect of substituted wheat flour with different levels of millet flour on the chemical-physicochemical properties, color, rheological properties as well as, on the physical properties, sensory, crust and crumb color and texture profile of the formulated pan bread.

\section{MATERIALS AND METHODS MATERIALS:}

Grains samples:

Hard red winter wheat grains (Triticum vulgare) were obtained from Egyptian Milling Technology Center during 2014/2015 seasons, the pearl millet grain (Pennisetum glaucum) hulled form, was obtained from Almizan Natural Trading ETS, Kingdom of Saudi Arabia. Dry yeast, sodium chloride, sugar, shortening, skimmed milk powder were obtained from local market.

\section{METHODS:}

1. Technological methods:

1.1. Preparation of grains:

Wheat and millet grains were cleaned and tempered to $16.5 \%$ moisture content for 8 and $24 \mathrm{hr}$, respectively. The grains were milled through a Quadrumat Senior Laboratory Mill (Brabender OHG, Model No 8802, Duisburg, Germany) according to AACC method 26-50 (2010).

\subsection{Preparation of pan bread:}

The wheat flour (100\% WF as control) was substituted with millet flour (MF) by $10 \% \quad(90 \% \quad W F+10 \% \quad M F), \quad 20 \% \quad(80 \%$ WF+20\% MF), $30 \%(70 \% \mathrm{WF}+30 \% \mathrm{MF})$ and $40 \%$ (60\% WF+40\% MF).

The straight dough process was performed in pan bread preparation according to AACC method 10-10B (2010). The bread dough formula consisted of the previous flour blends $(100 \mathrm{~g})$, dry yeast (3 $\mathrm{g})$, sodium chloride $(2 \mathrm{~g})$, sugar $(5 \mathrm{~g})$, shortening ( $3 \mathrm{~g})$, dry skimmed milk $(3 \mathrm{~g})$ and water (according to farinograph test).

\section{Proximate Chemical method:}

2.1. Proximate chemical composition:

Moisture, ash, protein $(\mathrm{N} \times 5.7)$, crude fat and crude fiber of blends were 
determined according to AACC methods (2010). The total carbohydrate content was calculated by difference as the following equation: Total carbohydrate \% $=100-($ ash $\%+$ crude protein $\%+$ crude lipid \%).

\subsection{Starch damage:}

Starch damage of blends (WF substituted with different levels of MF) was determined using $\mathbf{S D}_{\text {matic }}$ instruments (Chopin, Triplette et Renauld, Paris, France) according to AACC methods 76 33 (2010) by using the amperometric method.

\subsection{Gluten determination:}

Wet, dry gluten and gluten index of blends of WF substitute with different level of MF were determined using (Glutomatic perten instruments $A B$ type 2200, Huddinge, Sweden) according to AACC methods 38-12 (2010).

\section{Physicochemical method:}

3.1. Falling number:

Falling number of blends was determined using falling number $A B$ instrument (type 1402, No. 539 Stockholm, Sweden) according to AACC methods 5681 (2010)

\subsection{Color analysis:}

Color grade of WF and the other wheat/millet flour blends as well as its formulated pan bread (crust and crumb) was measured using SATAKE color grader (NCGA, Japan) with a D65 light source. The color parameters were measured as Lightness $\left(\mathrm{L}^{*}\right)$, Redness $\left(\mathrm{a}^{*}\right)$ and Yellowness $\left(b^{*}\right)$ as described by Mahmood (2015).

\subsection{Glutograph determination:}

Glutograph determination of wheat/millet flour blends was carried out according to the manual of the manufacturer (Brabender $\mathrm{GmbH}$ and $\mathrm{Co}$. Duisburg, Germany) of the glutograph-E according to Alamri et al. (2009a,b): wet gluten from $10 \mathrm{~g}$ of flour was used for measuring the stretching and elastic properties of the dough to obtain the following data: 1 . Shear time or stretching time (STR) as sec: time to reach the deflection or shear angle (determines the extension of the dough); and 2. Relaxation (RX) as BU: the recovery of the sample after $10 \mathrm{sec}$ (determine the elasticity of the dough).

\subsection{Solvent retention capacity profile:}

Solvent retention capacity (SRC) of wheat/millet flour blends was determined according to AACC method 56-11 (2010).

\subsection{Rheological Properties:}

Rheological properties of wheat/millet flour blends were carried out using Brabender ${ }^{\circledR}$ faringraph and extensograph according to AACC method 54-21 and 5410 (2010).

\subsection{Bread texture analysis:}

Texture analysis of baked loaves formulated from WF substituted with different levels of MF was carried out using texture analyzer (TA- $\mathrm{HDi}^{\circledR}$ Stable Micro Systems, Surrey, England). Texture profile analysis (TPA) with 2 compression cycles was used and samples were compressed using $35 \mathrm{~mm}$ cylindrical probe with $5 \mathrm{~kg}$ load cell. Just after cooling at room temperature $\left(25 \pm 2.0^{\circ} \mathrm{C}\right)$ and kept in transparent double zipper, Ziploc ${ }^{\circledR}$ bags, and stored for 6 days at room temperature $\left(25 \pm 2.0^{\circ} \mathrm{C}\right)$, texture measurement of bread was made using 3 central slices of about $25 \mathrm{~mm}$ total thickness (Bourne et al. 1978).

\subsection{Physical properties of pan bread:}

Weight (g) and volume $\left(\mathrm{cm}^{3}\right)$ by rapeseed displacement of coold bread loaf were recorded after cooling for $1 \mathrm{hr}$. Loaf specific volume $\left(\mathrm{cm}^{3} / \mathrm{g}\right)$ was calculated by dividing volume by weight 
as described by AACC methods 10-05 (2010).

\section{Sensory evaluation of pan bread:}

Sensory analysis including symmetry shape, crust color, break and shred, crumb texture, crumb color, aroma, taste, mouth feel and overall acceptability of the fresh pan breads was performed by 15 members of a panel of graduate students of staff, using a hedonic scale of global acceptance (9. Like extremely; 8 . Like very much; 7. Like moderately; 6 . Like slightly; 5. Neither like nor dislike; 4. Dislike slightly; 3. Dislike moderately; 2. Dislike very much; 1. Dislike extremely) (Ajila et al. 2008). Bread was evaluated after $3 \mathrm{hr}$ after baking, when loaves were sliced into $2 \mathrm{~cm}$ thick slices by a bread slicing machine. Panelists evaluate slices of different bread system which were offered at the same time in an open area without special lighting. Water was provided for rinsing purpose.

\section{Statistical analysis:}

Statistical analysis which data was performed using one way analysis of variance (ANOVA) followed by Duncan's Multiple Range Test with $(P \leq 0.05)$ degree being considered statistically significant. Statistical analyses were performed with the Statistical Analysis System software 9.2 (SAS Institute, Cary, NC, USA). While Factorial experiment was used to analyze the data of extensograph parameters and texture profile analyzer of bread (Montgomery 1984). Least significant difference (LSD) was followed to make the multiple comparisons. The significant difference was determined at $0.05 \%$ level.

\section{RESULTS AND DISCUSSION:}

1. Chemical and physicochemical characteristics of WF substituted with different levels of MF:

1.1. Proximate composition:
The proximate compositions of wheat flour substituted with different levels $(10 \%, 20 \%, 30 \%$ and $40 \%)$ of millet flour are shown in Table (1). Significant $(p \leq 0.05)$ increase was observed in moisture, total ash, total fat, and crude fiber by increasing the MF substitution levels. Meanwhile, the carbohydrate contents decreased $(p \leq 0.05)$ by increasing substitution levels of MF. Whereas, no difference $(P>0.05)$ was detected in total protein between WF and that substituted with up to $30 \%$ MF. These results are similar to those reported by Hadimani and Malleshi (1993); Coda et al. (2010) and Buresova et al. (2017). Vidya et al. (2013) showed that the proximate composition of the wheat flour was moisture $12.8 \%$, protein $11.8 \%$, fat $1.7 \%$ ash $1.5 \%$ and carbohydrate (by difference) $72.2 \%$. However, millet flour composition was moisture $12.3-12.5 \%$, protein $8.2-13 \%$, fat 1.5-5.1\%, ash $2.6-3.0 \%$ and carbohydrate (by difference). Gull et al. (2015) reported that the moisture and ash content of pearl millet flour was 13.49 and $0.73 \mathrm{~g} / 100 \mathrm{~g}$, respectively.

On the other side, significant $(p \leq 0.05)$ decrease was detected in gluten parameter by increasing MF substitution levels (except for the 10\% substitution levels which had no significant $(p>0.05)$ changes in wet gluten and gluten index). These observations are in agreement with the results obtained by Taylor et al. (2014); Gulati et al. (2016) and McSweeney et al. (2017). They reported that the millet although it being gluten free, it contains protein content similar to wheat and higher than commonly consumed gluten free crops. The significant highest $(p \leq 0.05)$ wet gluten ( 32.14 and $31.49 \%)$, dry gluten (12.59 and $11.06 \%$ ) and gluten index (95.94 and $94.11 \%)$ were given by WF and $90 \%$ WF $+M F 10 \%$, respectively. Also, significant $(p \leq 0.05)$ decrease in starch damage was observed by substitution WF with increasing levels of MF. 
Table (1): Proximate composition (on dry weight basis) and gluten parameters of wheat /millet flour blends:

\begin{tabular}{|c|c|c|c|c|c|c|c|}
\hline & \multirow{2}{*}{ MF } & \multirow{2}{*}{ WF } & \multicolumn{4}{|c|}{ Substitution levels (\%) } & \multirow{2}{*}{ LSD } \\
\hline & & & 10 & 20 & 30 & 40 & \\
\hline \multicolumn{8}{|c|}{ Proximate composition } \\
\hline Moisture & 11.85 & $13.70^{b}$ & $13.86^{a}$ & $13.77^{a}$ & $13.73^{a}$ & $13.83^{a}$ & 0.13 \\
\hline Total ash & 1.23 & $0.56^{e}$ & $0.63^{d}$ & $0.68^{c}$ & $0.76^{b}$ & $0.83^{a}$ & 0.03 \\
\hline Total protein & 14.54 & $14.03^{b}$ & $14.08^{b}$ & $14.13^{b}$ & $14.18^{\mathrm{ab}}$ & $14.32^{\mathrm{a}}$ & 0.18 \\
\hline Total fat & 4.80 & $1.06^{e}$ & $1.43^{d}$ & $1.81^{\mathrm{c}}$ & $2.18^{b}$ & $2.56^{a}$ & 0.02 \\
\hline Total Crude fiber & 4.32 & $1.05^{\mathrm{e}}$ & $1.38^{\mathrm{d}}$ & $1.70^{c}$ & $2.03^{b}$ & $2.36^{a}$ & 0.01 \\
\hline Starch damage (\%) & 3.17 & $5.74^{\mathrm{a}}$ & $5.48^{b}$ & $5.19^{c}$ & $4.85^{d}$ & $4.60^{\mathrm{e}}$ & 0.02 \\
\hline Total Carbohydrates & 64.41 & $64.91^{\mathrm{a}}$ & $64.52^{b}$ & $64.42^{c}$ & $64.30^{d}$ & $63.86^{e}$ & 0.17 \\
\hline \multicolumn{8}{|l|}{ Gluten parameters } \\
\hline Wet gluten & ND & $32.14^{a}$ & $31.49^{\mathrm{ab}}$ & $31.22^{b}$ & $28.33^{c}$ & $27.96^{c}$ & 0.78 \\
\hline Dry gluten & ND & $12.59^{a}$ & $11.06^{b}$ & $11.05^{b}$ & $10.20^{\mathrm{b}}$ & $9.88^{c}$ & 1.08 \\
\hline Gluten index & ND & $95.94^{a}$ & $94.11^{a b}$ & $91.92^{b}$ & $90.97^{b c}$ & $88.34^{c}$ & 3.15 \\
\hline
\end{tabular}

Data are mean of three replicates.

Values followed by different letters in the same row are significantly different $(P \leq 0.05)$.

Total carbohydrates by difference.

ND: not determined.

\subsection{Falling number (FN), glutograph and color degree parameters:}

Falling number (FN) test was carried out to measure amylolytic activity in flour (which indicates the alpha amylase enzyme activity). The FN values of WF was $594.26 \mathrm{sec}$ which agreed with the results obtained by Pasha, (2006) who reported that the falling number of pakistani wheats ranged from 243 to $648 \mathrm{sec}$ in fifty different wheat varieties. Significant decrease $(p \leq 0.05)$ was noticed by substitution WF with MF (Table 2). This might be indicating that there was higher alpha amylase activity in MF.

Flour color is important, not only as an alternative way of monitoring flour refinement but also as a predictor of color in products. Generally, increasing the substitution levels of MF resulted in a significant $(p \leq 0.05)$ decrease in lightness
$\left(L^{*}\right)$; redness to greenness $\left(a^{*}\right)$; hue angle $\left(h^{*}\right)$ and total color difference $\left(\Delta E^{*}\right)$ value. Meanwhile, increased $(p \leq 0.05)$ the yellowness to blueness $\left(b^{*}\right)$ and chroma $\left(c^{*}\right)$. The decrease in $L^{*}$ value may be attributed to the presence of dark colored flours of millet.

Significant $(P \leq 0.05) \quad$ increase in stretching values was noticed between control and the blends substituted with different level of MF. Also, no significant $(p>0.05)$ change was detected in relaxation values between control and up to $30 \% \mathrm{MF}$. The significant $(p \leq 0.05)$ highest (the maximum value that by glutograph registered) stretching value (304.33 sec.) and relaxation values (87.00 BU) were recorded for the blends of $60 \%$ WF+MF40\%, while the significant lowest $(p \leq 0.05)$ values (184.33 sec. and $55.67 \mathrm{BU}$, respectively) was detected in control samples. 


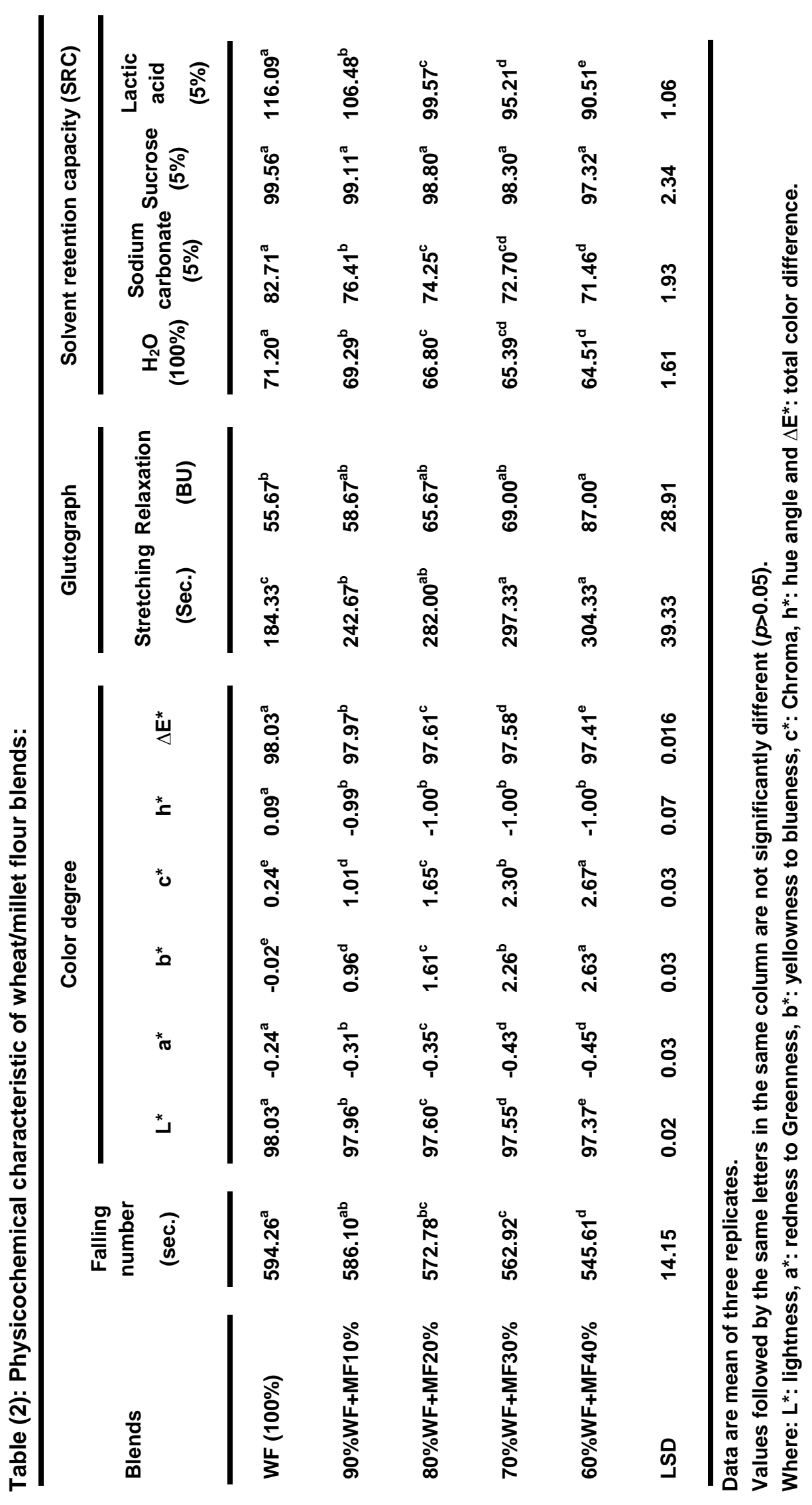


The stretching parameter of glutograph (dough strength parameter) strongly corresponds to the following dough strength parameters of the other instruments: Stability (Table 3); resistance to extension, area under the curve, maximum resistance (Table 4). In contrast, the relaxation parameter of the glutograph corresponds more to extensibility and length of curve than to stability, resistance to extension due to their negative correlations. Thus, glutograph dough strength parameters could possibly be used to replace other dough strength parameters obtained from other standard rheological dough.

\subsection{Solvent retention capacity profile (SRC):}

Water absorption is essential for determining the effect of any additive to wheat flour that might change the dynamics of water in the dough syste $m$. Data in Table (2) proposed that a significant $(p \leq 0.05)$ decrease was observed in all solvent retention capacity profile (SRC) parameters by increasing the substitution levels of MF. The decrease in sodium carbonate retention might be due to its reaction with the damaged starch in flour which decreased with increasing the substitution levels. The increase in $\mathrm{Na}_{2} \mathrm{CO}_{3}$ value (compared to $\mathrm{H}_{2} \mathrm{O} \mathrm{SRC}$ ) could be explained by high $\mathrm{pH}$ of sodium carbonate which increased the water absorption due to the ionization of the hydroxyl groups of the blends including starch that allows for hydrogen bonding (Gains 2000).

No significant $(P>0.05)$ change in sucrose SRC between WF and WF/MF blend up to $40 \%$ substitution. This may be due to its lower levels of pentosans content. Sucrose SRC indicated primarily the pentosan effects and some contribution of the gliadin proteins (Kiszonas et al. 2013).

Lactic acid SRC value of control was $116.09 \%$ which is gradually decreased by increasing the substituting levels in the blend of MF to reach the significant lowest value of 90.51 in $60 \% \mathrm{WF}+40 \% \mathrm{MF}$. These observations are in agreement with the results obtained by Duyvejonck et al. (2011) who mentioned that the lactic acid SRC values fluctuated $106.4 \%$ to $147.1 \%$ for wheat samples with protein content range $10.7 \%$ to $14.6 \%$. Lactic acid SRC, didn't affect by total protein (Kiszonas et al. 2013) meanwhile, it positively correlated with glutenin content (Colombo et al. 2008).

The significant $(p \leq 0.05) \quad$ highest distilled water, sodium carbonate, sucrose and lactic acid SRC,s values $71.20,82.71, \quad 99.56$ and $116.09 \%$, respectively were recorded by control, while the significant $(p \leq 0.05) \quad$ lowest values $64.51,71.46,97.32$ and $90.51 \%$, respectively were given at $60 \% W F+40 \%$ MF blend.

2. Effect of substituting wheat flour with different levels of millet flour on rheological parameters:

The amount of absorbed water is significant $(p \leq 0.05)$ increased as the substitution levels of MF in the WF/MF blend increased. Where by increasing the amount of MF from $30 \%$ to $40 \%$ substitution, water absorption decreased from $59.5 \%$ to $57.8 \%$ (Table 3). This observation in full agreement with those reported by Saha et al. (2011) and Crassina et al. (2012) who reported that water absorption by millet flour is generally lower than that of wheat flour.

The total absorbed water by starch in dough is $45.5 \%$, proteins $31.2 \%$ and $23.4 \%$ by pentosans. Thus, water absorbation may not be directly related to gluten strength and may be influenced more by other factors such as starch damage and pentosans contents. Differences in water absorption might also be related to differences in chemical and protein composition (Markowski et al. 2006). 


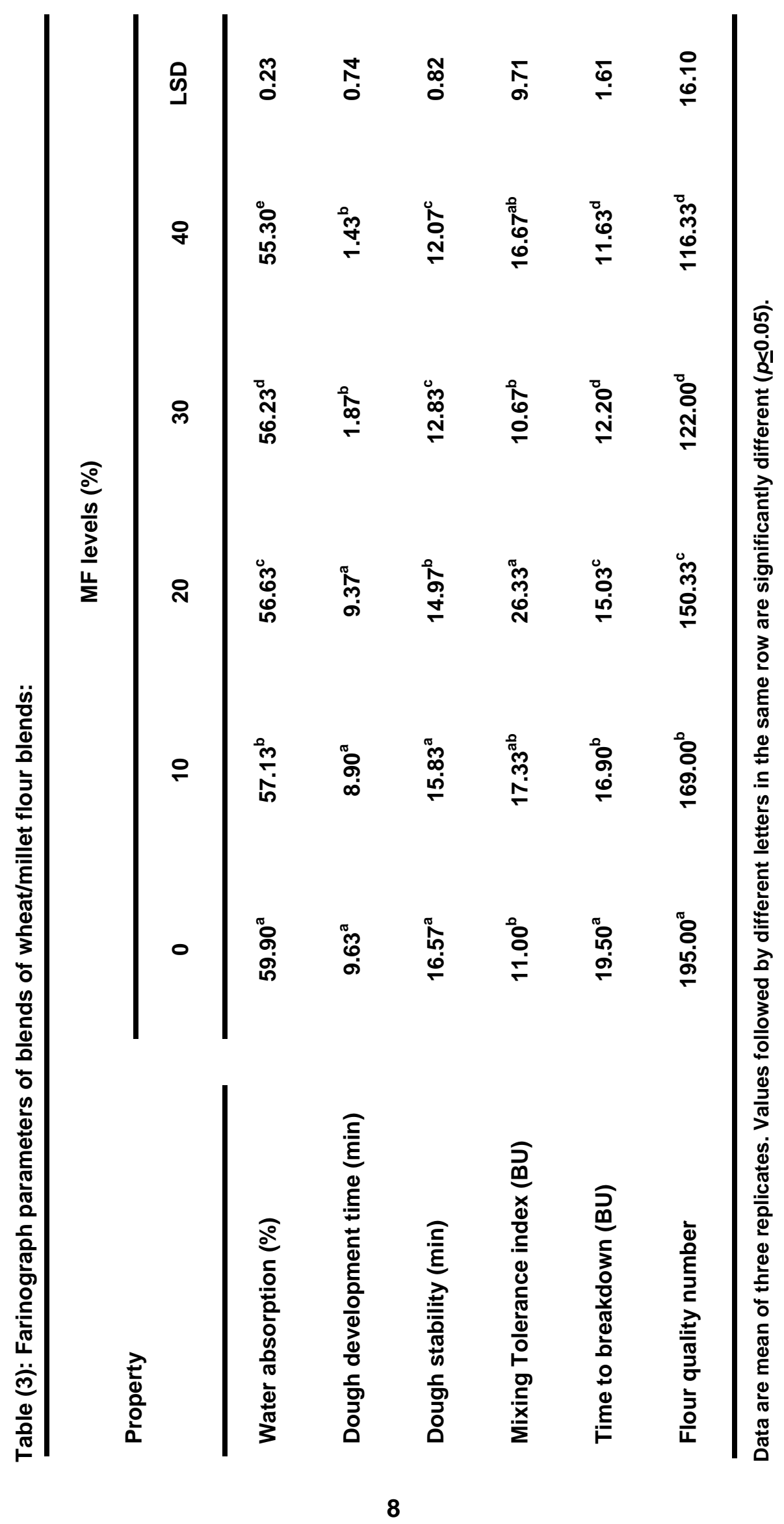




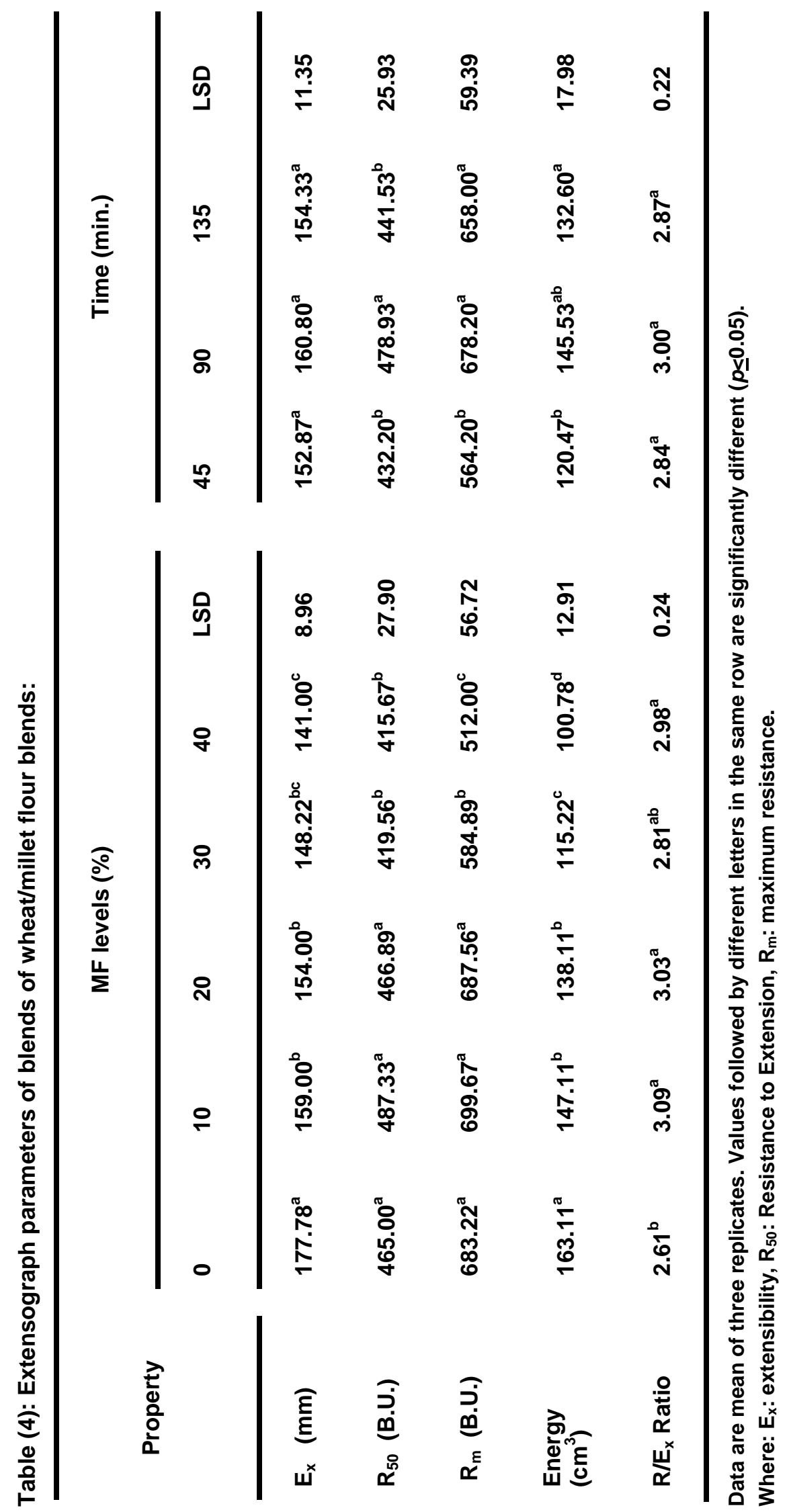


No significant $(p>0.05)$ change in dough development time was observed between WF and that substituted with MF up to $20 \%$, while, significant $(p \leq 0.05)$ decrease was observed by increasing the substitution up to $40 \%$. This may be due to competition for water and consequent delayed development of the gluten network (Jacobs et al. 2008 and Rieder et al. 2012).

Dough stability time (DST) did not significant $(p>0.05)$ change by replacing WF with MF up to $10 \%$. Meanwhile, a significant $(p \leq 0.05)$ decrease in DST was detected up to 20 and $30 \%$ MF substitution. The highest dough stability values were 16.57 and $15.83 \mathrm{~min}$ detected in WF and that substituted with MF up to $10 \%$. The decrease in stability with the increasing replacement levels of MF in the blends may be attributed to the dilution or weakening of the gluten matrix (Crassina et al. 2012). The higher value of stability time was confirmed by the increase of wet gluten (Table 1). These observations are in agreement with the results obtained by Marco and Rosell (2008) who found that the high stability values are usually related to the strength of flour.

Generally, no significant $(p>0.05)$ change in MTI was observed between control and that substituted with up to $10 \%$ MF. Data also showed that significant $(p \leq 0.05)$ reduction difference in Time to breakdown and farinograph quality number (FQN) was observed between control and substitution with MF at different level. Higher FQN, in general, indicates strong flour with better stability, as it is supported by the stability data (Bojňanská et al. 2013).

Extensograph properties of all dough samples were found to be dependent on level of substitution and proving time (Table 4). For regarding substitution levels, Significant $(p \leq 0.05)$ decrease was detected in extensibility (Ex) and energy (E) between WF and that substituted with
MF; Meanwhile, significant increase $(p \leq 0.05)$ in $R / E_{x}$ Ratio, may be attributed to the polymeric protein structure. Extensibility decreased from 177.78 to $141.00 \mathrm{~mm}$ when wheat flour was replaced with $40 \%$ of MF, this is in agreement with the report of Saha et al. (2011).

Generally, no significant $(p>0.05)$ differences in resistance to extension $\left(\mathbf{R}_{50}\right)$ and maximum resistance $\left(\mathbf{R}_{\mathrm{m}}\right)$ were detected between WF and substitution up to $20 \%$ MF. Weipert (2006) stated that the dough with R/E ratio of 1.5 to 3.0 is thought to be of good quality, and could provide higher final baked volume.

Regarding rest time in Table 4, increasing the experimental time (from 45$135 \mathrm{~min})$ had no significant $(p>0.05)$ change in $E_{x}$. While, significant $(p \leq 0.05)$ increase was detected in $R_{50}$ between 45 to $90 \mathrm{~min}$.

The dough $R_{m}$ was significantly $(P \leq 0.05)$ increased with increasing resting time. At the same time, increasing the experimental time (from 45-90 $\mathrm{min}$ ) showed no significant $(p>0.05)$ changes in energy and $R / E_{x}$ Ratio. The statistical analysis revealed that the best rest time was $90 \mathrm{~min}$, while worst at $45 \mathrm{~min}$.

3. Baking properties of pan bread formulated with WF and different levels of MF:

\subsection{Physical properties:}

The physical characteristics (weight, loaf volume and specific volume) are an elementary prediction of quality of pan bread, the dough and pan bread formulated with the different levels of MF (Table 5).

Generally, no significant $(p>0.05)$ change in loaf weight, loaf volume and specific volume were found between WF and bread substituted with MF at $10 \%$. Meanwhile, pan bread formulated with more than $10 \%$ MF had a higher $(p \leq 0.05)$ weight compared with control, which 


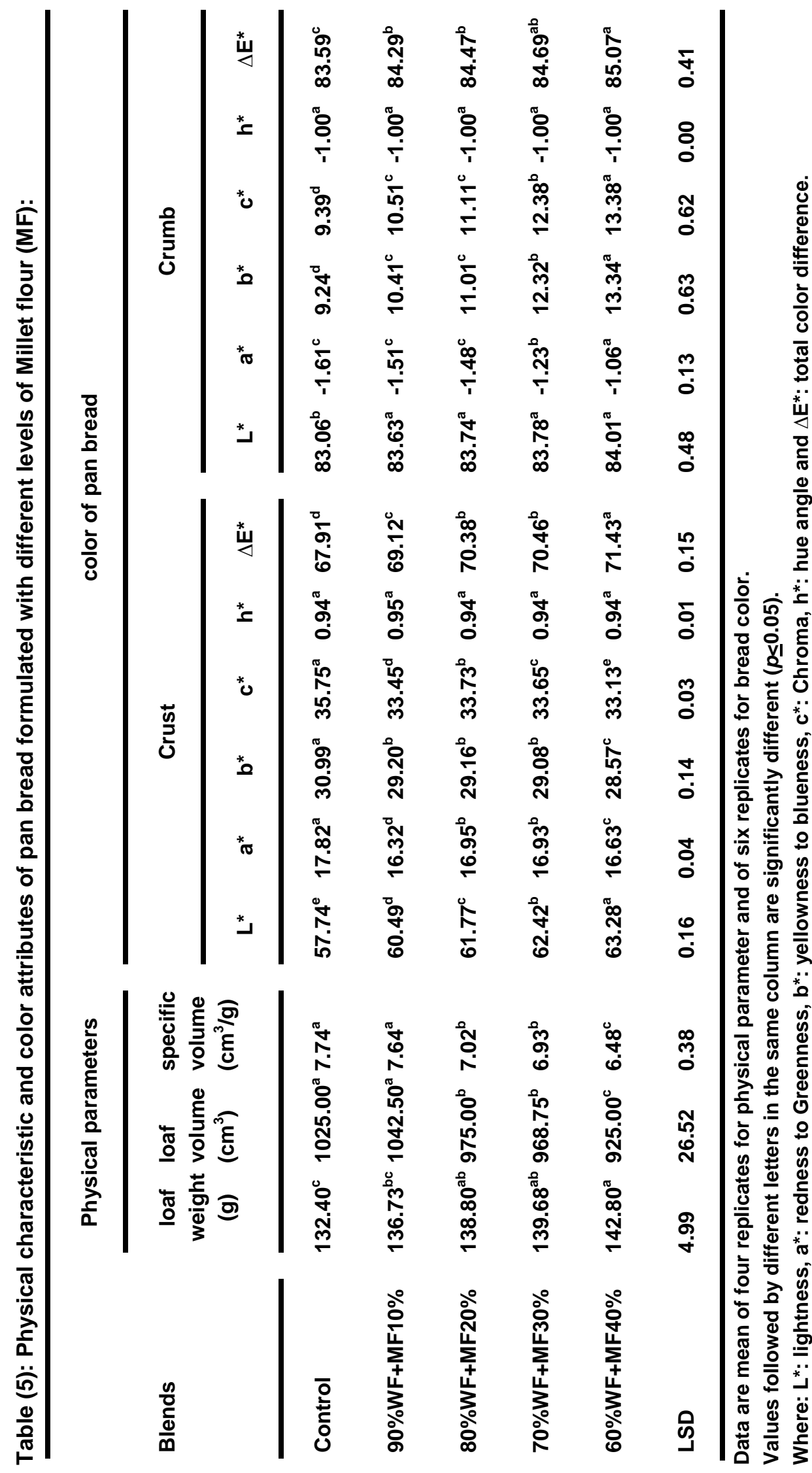


caused a reduction in bread quality gradually as well as, the dough was too dry and firm, and a more irregular structure with most gluten layers without a continuous distribution and surrounded by large starch granules, which might be probably due to a gluten dilution effect and/or the increase of alkaline-insoluble protein, which is strongly linked with dough mixing poor quality (Swec and Hruskova 2010; Regine et al., 2013; Monika et al., 2015 and Mamata 2015).

\subsection{Crust and crumb color of pan bread:}

Significant $(P \leq 0.05)$ increase was detected in $L^{*}$ and $\Delta E^{*}$ by increasing MF; which means an increase in crust lighteness when the millet concentration was raised (Table 5). Results indicated that the crumb lightness $\left(L^{*}\right)$ of breads became lighter $(p \leq 0.05)$ when higher levels of MF were incorporated into breads, the highest $L^{*}$ value (84.01) was detected at up to $40 \%$ MF. This may be due to creamish white color of pearl millet flour and/or decreased starch damage and/or higher alpha amylase activity. Similar findings were reported by Sharma and Gujral (2014) and Basman and Kokse I (2001) who demonstrated that the incorporation of barley flour to wheat flour increased the lightness $\left(L^{*}\right)$ and yellowness $\left(b^{*}\right)$ during Turkish flat bread preparation. Also, significant $(p \leq 0.05)$ increase in $b^{*}, c^{*}$, and $\Delta E^{*}$. At the same time, no significant $(p>0.05)$ affect in $a^{*}$ between WF and up to $20 \%$ MF and up to $40 \%$ for $h^{*}$.

\subsection{Texture Profile Analysis parameter:}

Texture profile analysis (TPA) is a very useful technique for investigating food products. No significant $(p>0.05)$ difference was detected in hardness, adhesiveness, gumminess and chewiness between WF and the substituted with different levels of MF, While springiness, cohesiveness and resilience up to $30 \%$ MF (Table 6).
On the other hand, the hardness, gumminess and chewiness values significantly $(p \leq 0.05) \quad$ increased by increasing the storage time (six day). Meanwhile, cohesiveness and resilience decreased $(p \leq 0.05)$. Data also showed that no difference $(p>0.05)$ in adhesiveness and springiness between freshly prepared bread and after four to six days storage, respectively. This may be attributed to the low moisture levels and / or caused harder and denser crumb structure breads with increasing storage time by change the quality of protein in the WF+MF bread system. Such data are in line with those obtained by Crassina et al. (2012); Ballolli et al. (2014) and Bhol and Sowriappan (2014).

The values of the maximum cohesiveness are higher in case of WF (0.54s). Such data are in line with those obtained by Saha et al. (2011) who mentioned that the increased gluten content in wheat flour increased the cohesive property of the dough and due to the plasticity of gluten.

\subsection{Sensory characteristics:}

No significant $(p>0.05)$ changes in symmetry shape, crumb color and mouth feel were noticed between WF and up to $30 \%$ MF (and up to $40 \%$ of crust color); While, break and shred, crumb texture and taste had no changes $(p>0.05)$ up to $20 \%$ (Table 7 and Figure 1). Meanwhile, significant $(p \leq 0.05)$ decrease was detected in aroma by increasing MF. The arbitrator's acceptance to control was like very much, while substitution up to $20 \%$ was like moderately and at 30 and $\mathbf{4 0 \%}$ was like slightly.

Wheat flour substituted with different millet flour levels was identified in a previous work (Angioloni and Collar 2012a) and corresponds to the maximum tolerated levels of non-wheat cereals to produce sensorial accepted breads. 


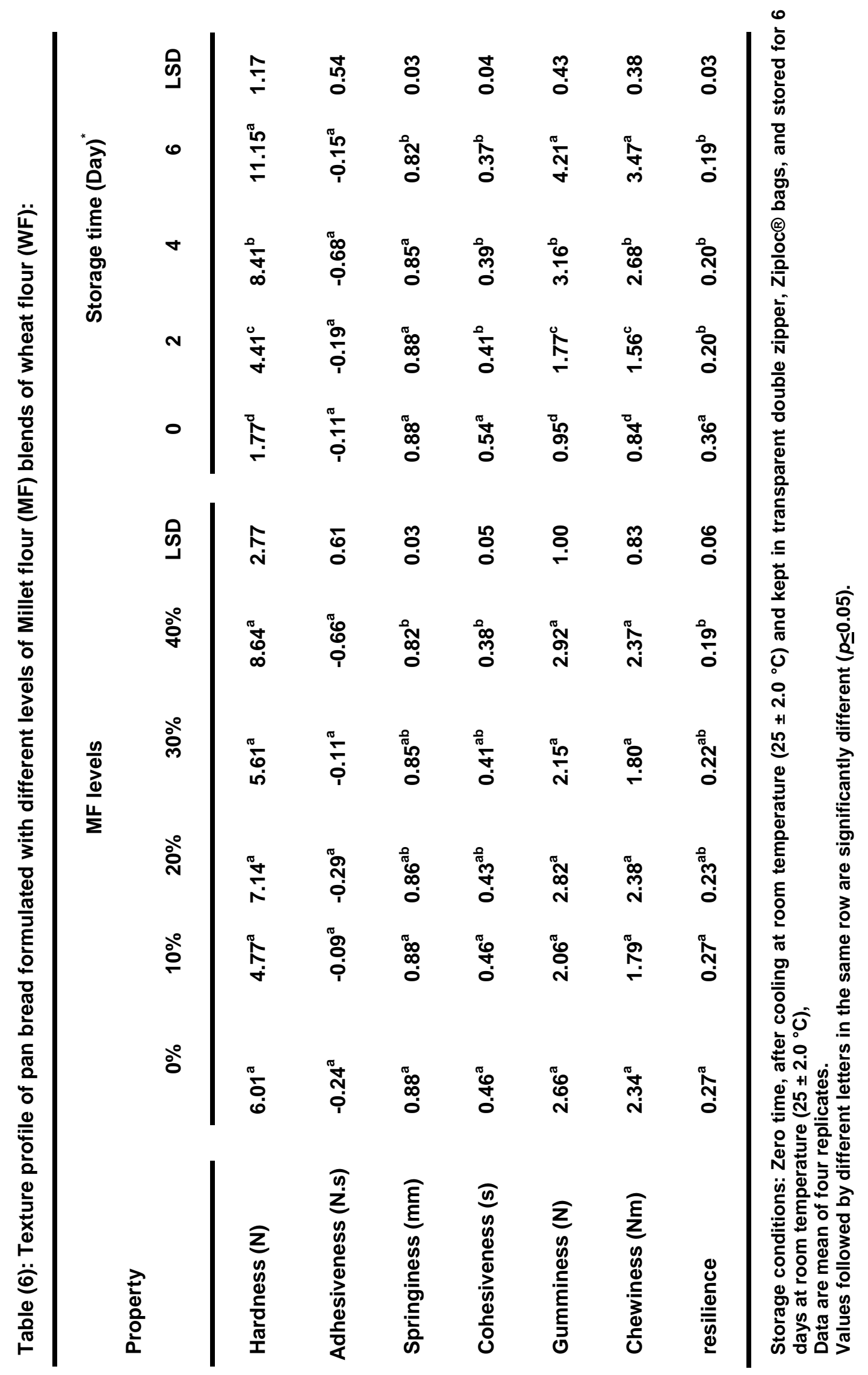




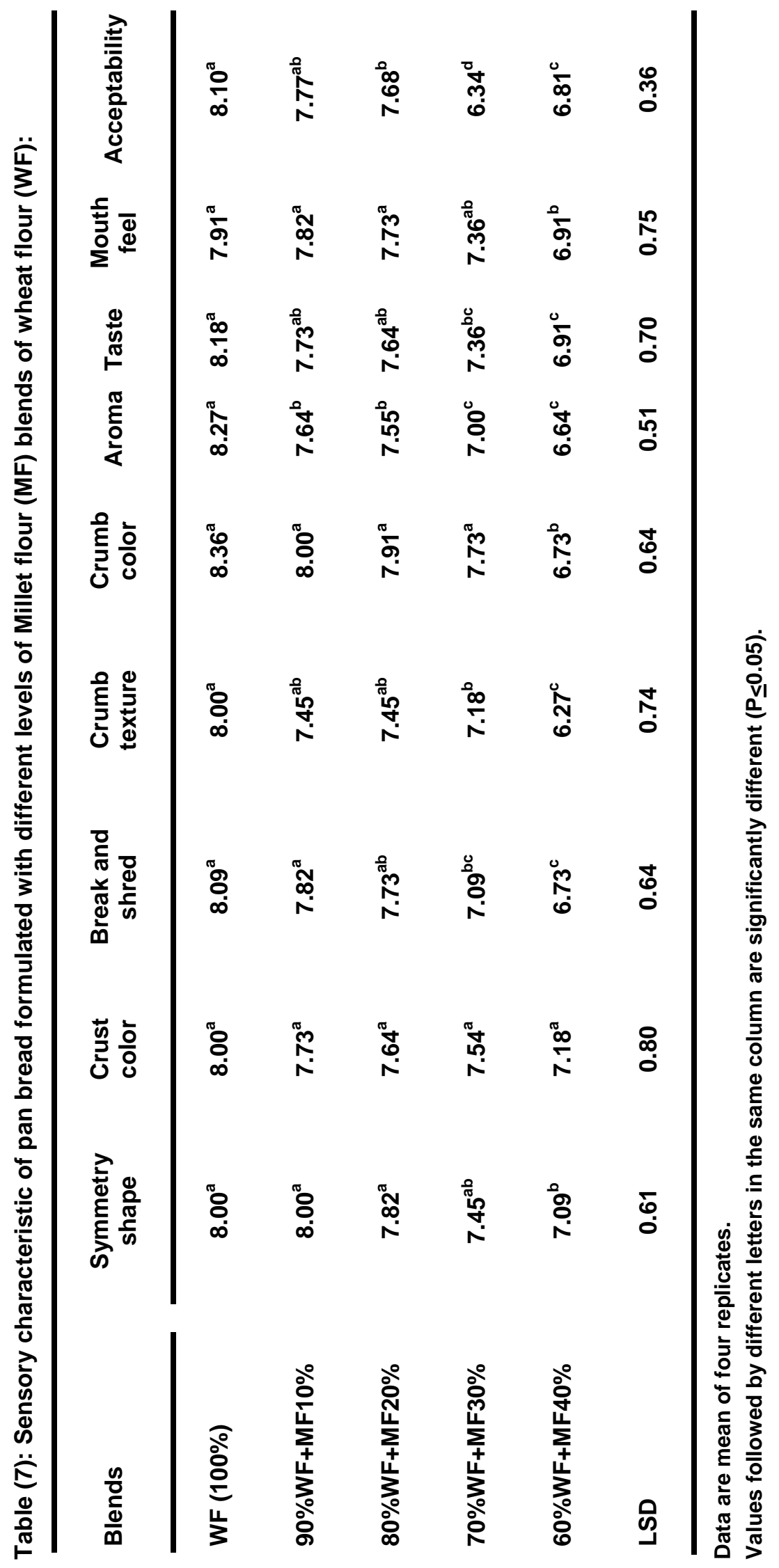


Evaluation of a novel pan bread formulated by wheat/millet flour different blends

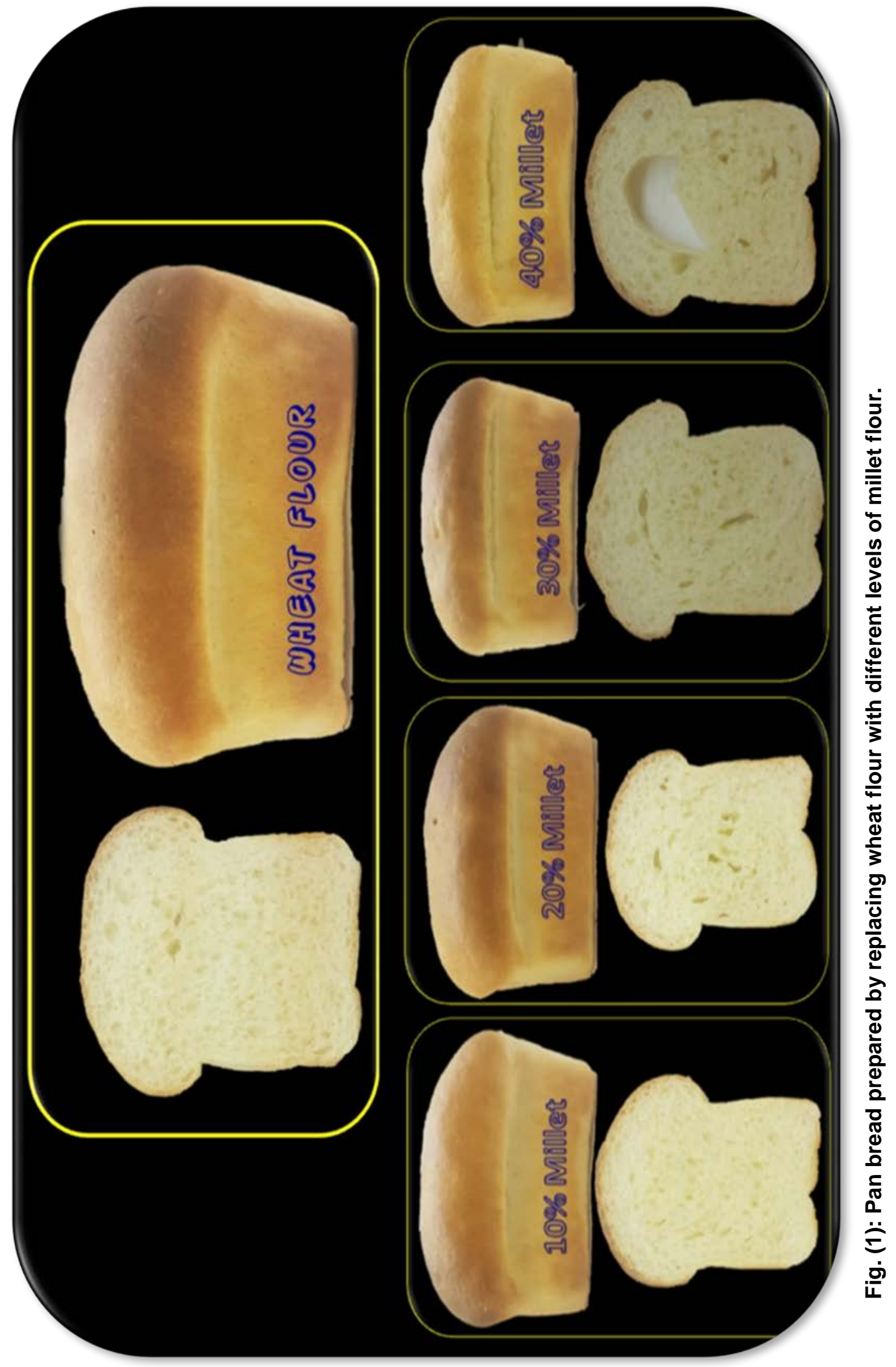




\section{CONCLUSION}

Substitution of wheat flour with MF up to $10 \%$ did not affect significantly $(p>0.05)$ on chemical and rheological attributes of dough wet gluten, dough development time, stability time, while sensory characteristics of formulated pan breads were acceptable even at $30 \%$ substitution level. In this context, the unique technological characteristic of millet deserves special attention for substitution, at least in the traditional cereal-based products.

\section{REFERANCES}

AACC (2010). Approved Methods of the American Association of Cereal Chemists, $11^{\text {th }}$ ed. St. Paul, MN. AACC International. Available online only.

http://methods.aaccnet.org/about.aspx.

Ajila, C. M., K. Leelavathi and U. J. S. Prasada-Rao (2008). Improvement of dietary fiber content and antioxidant properties in soft dough biscuits with the incorporation of mango peel powder. Journal of Cereal Science, 48: 319-326.

Alamri, M.S., F. Manthey, M. Mergoum, E.M. Elias and K. Khan (2009a). Use of the glutograph instrument in durum wheat quality evaluation. Plant Science Research, 2: 23-32.

Alamri, M., F. Manthey, M. Mergoum, E. Elias and K. Khan (2009b). Assessing spring wheat quality using the glutograph instrument. Cereal Foods World, 54: 124-131.

Altındag, G., M. Certel, F. Erem and Ü. I. Konak (2015). Quality characteristics of gluten-free cookies made of buckwheat, corn, and rice flour with/without transglutaminase. Food Science and Technology International, 21: 213-220.

Amadou, I., M.E. Gounga and G.W. Le (2013). Millets: nutritional composition, some health benefits and processing -
A review. Food Science and Nutrition, 25: 501-508.

Angioloni, A. and C. Collar (2012). Suitability of oat, millet and sorghum in bread making. Food Bioprocess Technology, 6:1486-1493.

Angioloni, A. and C. Collar (2012a). Promoting dough viscoelastic structure in composite cereal matrices by high hydrostatic pressure. Journal of Food Engineering, 111: 598-615.

Balasubramanian, S. and R. Viswanathan (2010). Influence of moisture content on physical properties of minor millets. Journal of Food Science and Technology, 4: 279-284.

Balasubramanian, S., J. Kaur and D. Singh (2014a). Optimization of weaning mix based on malted and extruded pearl millet and barley. Journal of Food Science and Technology, 51: 682-690.

Balasubramanian, S., D. N. Yadav, J. Kaur and T. Anand (2014b). Development and shelf-life evaluation of pearl millet based upma dry mix. Journal of Food Science and Technology, 51: 1110-117.

Ballolli, U., U. Malagi, N. Yenagi, V. Orsat and Y. Gariepy (2014). Development and quality evaluation of foxtail millet [Setariaitalica (L.)] incorporated breads. Journal of Agricultural Science, 27: 52-54.

Barca, de la A.M.C., R. M.E. Martínez, I. A.R. Rubio and C. F. Chavez (2010). Gluten- free breads and cookies of raw and popped amaranth flours with attractive technological and nutritional qualities. Plant Foods for Human Nutrition, 65:241-246.

Basman, A. and H. Koksel (2001). Effects of barley flour and wheat bran supplementation on the properties and composition of Turkish flat bread, yufka. European Food Research and Technology, 212: 198-202.

Bhol, S. and J. D. B. Sowriappan (2014). Influence of malted finger millet and red kidney bean flour on quality 
characteristics of developed bread. Food Science and Technology, 55: 294300.

Bojňanská, T., M. Tokár, K. Mocko, H. Balková, H. Frančáková, E. Ivanišová and T. Roháčik (2013). Evaluation of new varieties of summer wheat triticuevaluation of new varieties of summer wheat triticuevaluation of new var. Journal of Microbiology, Biotechnology and Food Sciences. 2 (Special issue):1281-1292.

Bourne, M. C., J. F. Kenny and J. Barnard (1978). Computer - assisted readout of data from texture profile analysis curves. Journal of Texture Studies, 9: 481-494.

Buresova, I., T. Marian, M. Jan, H. Ludek, F. Oldrich and S. Viera (2017). The comparison of the effect of added amaranth, buckwheat, chickpea, corn, millet and quinoa flour on rice dough rheological characteristics, textural and sensory quality of bread. Journal of Cereal Science, 75: 158-164.

Chung, H. J., A. Cho and S. T. Lim (2014). Utilization of germinated and heat moisture treated brown rices in sugarsnap cookies. Food Science and Technology, 57: 260-266.

Coda, R., G. Carlo and G. Marco (2010). Use of sourdough fermentation and pseudo-cereals and leguminous flours for the making of a functional bread enriched of $Y$-aminobutyric acid (GABA). International Journal of Food Microbiology, 137: 236-245.

Colombo, A., G. Pérez, P. Ribotta and A. Leon (2008). A comparative study of Physicochemical tests for quality prediction of Argentine wheat flours used as corrector flours and for cookie production. Journal of Cereal Science, 48: $775-780$.

Crassina, A. S., G. Sheetal and R. Venkateswara (2012). Effect of native and germinated finger millet flour on rheological and sensory characteristics of biscuits.
International Journal of Food Science and Technology, 47: 2413-2420.

Desai, A.D., S.S. Kulkarni, A.K. Sahoo, R.C. Ranveer and P.B. Dandge (2010). Effect of supplementation of malted ragi flour on the nutritional and sensorial quality characteristics of cake. Advance Journal of Food Science and Technology, 2: 67-71.

Devi, P. B., R. Vijayabharathi, S. Sathyabama, N. G. Malleshi and V. B. Priyadarisini (2014). Health benefits of finger millet (Eleusine coracana L.) polyphenols and dietary fiber: A review. Journal of Food Science and Technology, 51: 1021-1040.

Duta, D. E. and A. Culetu (2015). Evaluation of rheological, physicochemical, thermal, mechanical and sensory properties of oat-based gluten free cookies. Journal of Food Engineering, 162: 1-8.

Duyvejonck, A.E., B. Lagrain, B. Pareyt, C.M. Courtin and J.A. Delcour (2011). Relative contribution of wheat flour constituents to Solvent Retention Capacity profiles of European wheat. Journal of Cereal Science, 53: 312-318.

FAO, (2017). GIEWS - Global Information and Early Warning System. Available on the intrnet at http://www.fao.org/giews/countrybrief/ country.jsp?code $=E G Y$.

FAOSTAT, (2011). FAOSTAT-agriculture, Production, Crops. FAOSTAT.

Available on the intrnet at http://faostat.fao.

Gains, C.S. (2000). Collaborative study of methods for solvent retention capacity profiles (AACC method 56-11). Cereal Foods World, 45: 303-306.

Gulati, P., S.A. Weier, D. Santra, J. Subbiah and D.J. Rose (2016). Effects of feed moisture and extruder screw speed and temperature on physical characteristics and antioxidant activity of extruded proso millet (Panicum miliaceum) flour. International Journal 
of Food Science and Technology, 51: 114-122.

Gull, A., P. Kamlesh and K. Pradyuman (2015). Effect of millet flours and carrot pomace on cooking qualities, color and texture of developed pasta. Food Science and Technology, 63: 470474.

Hadimani, N. A. and N. G. Malleshi (1993). Studies on milling, physicochemical properties, nutrient composition and dietary fibre content of millets. Journal of Food Science and Technology, 30: 17-20.

Izydorczyk, MS. and J. E. Dexte (2008). Barley $\beta$-glucans and arabinoxylans: molecular structure, physicochemical properties, and uses in food productsa review. Food Research International, 41: 850-868.

Jacobs, M.S., M.S. Izydorczyk, K.R. Preston and J.E. Dexter (2008). Evaluation of baking procedures for incorporation of barley roller milling fractions containing high levels of dietary fibre into bread. Journal of the Science of Food and Agriculture, 88: 558- 568.

Jideani, I.A. and V.A. Jideani (2011). Developments on the cereal grains Digitaria exilis (acha) and Digitaria iburua (iburu). Journal of Food Science and Technology, 48: 251-259.

Kaur, G., S. Sharma, H. P. S. Nagi and B. N. Dar (2012). Functional properties of pasta enriched with variable cereal brans. Journal of Food Science and Technology, 49: 467-474.

Kaur, M., K. S. Sandhu, A. Arora and A. Sharma (2015). Gluten free biscuits prepared from buckwheat flour by incorporation of various gums: physicochemical and sensory properties. Food Science and Technology, 62: 628-632.

Kiszonas, A. M., E. P. Fuerst and C. F. Morris (2013). A Comprehensive survey of soft wheat grain quality in
U.S. germplasm. Cereal Chemistry, 90: 47-57.

Krishnan, M. and P. Prabhasankar (2010). Effect of pasting, microstructure, sensory and nutritional profile of pasta influenced by sprouted finger millet (Eleucina Coracana) and green banana (Musa Paradisiaca) flours. Journal of Texture Studies, 41: 825-841.

Krishnan, R., U. Dharmaraj, R. S. Manohar and N. G. Malleshi (2011). Quality characteristics of biscuits prepared from finger millet seed coat based composite flour. Food Chemistry, 129: 499-506.

Mahmood, K. (2015). Cordia myxa Gum: Physico-Chemical Characterization and Bread Making. MSc Thesis, Food Science and Nutrition Department at the College of Food and Agriculture Sciences, K S U.

Mamata, M., Y. Nirmala and O. Valerie (2015). Quality evaluation of little millet (Panicum miliare) incorporated functional bread. Journal of Food Science and Technology, 52: 83578363.

Marco, C. and C. M. Rosell (2008). Breadmaking performance of protein enriched, glutenfree breads. European Food Research and Technology, 227: 1205-1213.

Markowski, M., A. Ratajski, H. Konopko, P. Zapotoczny and K. Majewska (2006). Rheological behavior of hot-air-puffed amaranth seeds. International Journal of Food Properties, 9: 195-203

McSweeney, M.B., K. Seetharaman, D.D. Ramdath and L.M. Duizer (2017). Chemical and physical characteristics of proso millet (Panicum miliaceum) based products. Cereal Chemistry, 94 : 357- 362.

Monika, H., I. Esther and M. Vicente (2015). Bread with whole quinoa flour and bifidobacterial phytases increases dietary mineral intake and bioavailability. Food Science and Technology, 60: 71-77. 
Montgomery, D.C. (1984). Design and analysis experiments. $2^{\text {nd }}$ Ed., John Wiley and Sons. New York, Toronto and chichester.

Osman, MA. (2011). Effect of traditional fermentation process on the nutrient and antinutrient contents of pearl millet during preparation of Lohoh. Journal of the Saudi Society of Agricultural Sciences, 10: 1- 6 .

Pasha, I. (2006). Biochemical characterization of Pakistani wheats in relation to grain hardness. Ph.D Thesis. Inst. Food Sci. and Technology, University of Agriculture, Faisalabad, Pakistan.

Rai, S., A. Kaur and B. Singh (2014). Quality characteristics of gluten free cookies prepared from different flour combinations. Journal of Food Science and Technology, 51: 785-789.

Regine, S., S. Marta, B. Attila and T. Sandor (2013). Optimisation of bread quality produced from wheat and proso millet (Panicum miliaceum L.) by adding emulsifiers, transglutaminase and xylanase. Food Science and Technology, 51: 361-366.

Rieder, A., S. Grimmer, F. L. Aachmann, B. Westereng, S. O. Kolset and S. H. Knutsen (2012). Generic tools to assess genuine carbohydrate specific effects on in vitro immune modulation exemplified by beta-glucans. Carbohydrate Polymers, 92: 2075-2083.

Saha, S., A. Gupta, S.R. Singh, K.P. NidhiBharti, V. M. Singh and H.S. Gupta (2011). Compositional and varietal influence on finger millet flour on rheological properties of dough and quality of biscuit. Food Science and Technology, 44: 616-621.

Saleh, A.S., Q. Zhang, J. Chen and Q. Shen (2013). Millet grains: nutritional quality, processing, and potential health benefits. Comprehensive Reviews in Food Science and Food Safety, 12: 281-295.

Sharma, P. and H. S. Gujral (2014). Antioxidant potential of wheat flour chapattis as affected by incorporating barley flour. Food Science and Technology, 56: 118-123.

Shimelis Admassu1 (2009). Chemical composition of local and improved finger millets composition of local and improved finger millet [eleusine corocana (L.) gaetrting] varieties grown in Ethiopia. Ethiopian Journal of Health Sciences. Vol. 19: No. 1.

Singh, KP., A. Mishra and H.N. Mishra (2012). Fuzzy analysis of sensory attributes of bread prepared from millet-based composite flours. Food Science Technolcs, 48: 276-282.

Supriya, A., S. Senapathy, C.T. Hash, N. Thirunavukkarasu, R. Vengaldas, E. Kankanti, R. Sharma, R.P. Thakur, P.R. Veeranki, R.C. Yadav and R.K. Srivastava (2016). QTL mapping of pearl millet rust resistance using an integrated DArT- and SSR-based linkage map. Euphytica, 209: 461-476.

Swec, I. and M. Hrusková (2010). Evaluation of wheat bread features. Journal of Food Engineering, 209: 461476.

Taylor, J.R.N., P.S. Belton, T. Beta and K.G. Duodu (2014). Increasing the utilization of sorghum, millets and pseudocereals: developments in the science of their phenolic phytochemicals, bio-fortification and protein functionality. Journal of Food Science, 59: 257-275.

Vidya, S. and R. Ravi (2013). Effect of Thermal Treatment on Selected Cereals and Millets Flour Doughs and Their Baking Quality. Food Bioprocess Technology, 6: 1218-1227.

Weipert, D. (2006). Fundamentals of rheology and spectrometry. In: Popper, L., Schafer, W. and Freund, W. (Eds.). Future of Flour a Compendium of Flour Improvement. Agrimedia, Bergen, Dunne, Germany. Pp. 117-146.

Yadav, O.P. and K.N. Rai (2013). Genetic improvement of pearl millet in India. Agricultural Research, 2: 275-292. 


\section{"تقييم خبز القوالب المعد بإستبدال دقيق القمح بلقيق الاخن"}

عماد شعبان السيد البرعى(1)، علاء الدين السيد البلتاجى(2)، طارق أحمد العدوى(2)

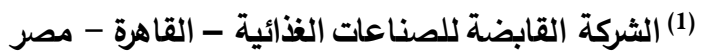

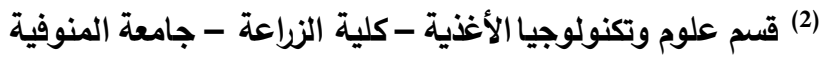

$$
\text { الملخص العربى }
$$

هدفت الدراسة الي معرفة تأثير استبدال دقيق القدح بنسب مختلفة من دقيق الاخن على الخصائص الكيميائية

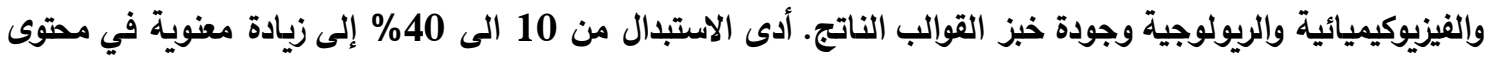

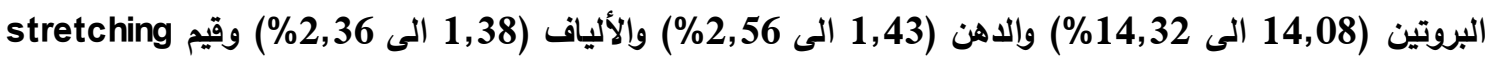
بينما إنخفض محتوى الكربوهيدرات الكلى والجلوتين الرطب والجلوتين الجاف وقيم قرة الدقيق على الإحتفاظبالمذيبات وقيم

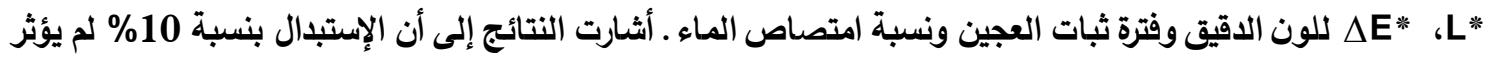

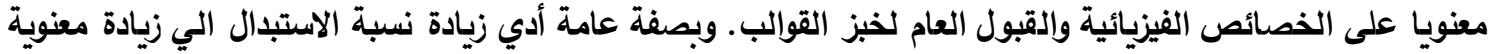

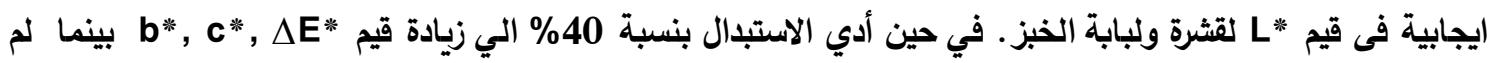

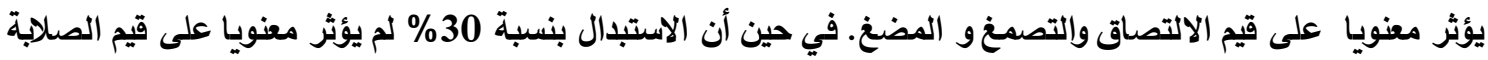

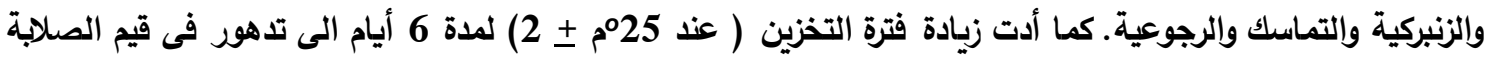

